\title{
Ethnobotany Medicinal Plants For Local Community in Southwest Sumba District
}

\author{
Elly Purwanti \\ University of Muhammadiyah Malang, \\ purwantielly@ymail.com
}

\author{
Tri Mulyatin \\ University of Muhammadiyah Malang
}

\begin{abstract}
Ethnobotany is a science that studies a correlation between humans and plants as part of natural resources. The aims of this study were: 1 . to know the type of medicinal plants used by the local community of Southwest Sumba; 2 . to find the benefits of medicinal plants obtained by local community; 3 . to observe how the community treats the medicinal plants; 4 . to identify the types of diseases that can be cured by the medicinal plants. This study employed descriptive explorative method. Based on the interview and direct observation in the research area, medicinal plants were found and utilized by villagers. There are 17 species that most widely used. In some areas of Southwest Sumba, the communities have their own system of the utilization of the medicinal plants. The systems they used are unique and different from one region to the others. Southwest Sumba people are still familiar with the various types of medicinal plants and their benefits, also how to treat them. The communities are able to integrate a culture of crop used as herbal medicine as an effort of conservation against local biodiversity. It can be concluded that the community still have strong efforts to cultivate medicinal plants.
\end{abstract}

Keywords: ethnobotany, medicinal plant, local community

\section{INTRODUCTION}

The ethnobotany study is a science that studies a correlation between humans and plants as part of natural resources (1). Each species of the plant diversity has its own benefits, for example they can produce chemicals that can be used for the cure of certain diseases, so we call it medicinal plants.

Medicinal plants spread throughout Indonesian archipelago and some of them grow as endemic plants (9). The utilization of medicinal plants in Indonesia as a cure for health problems have been existing for a long period. It can be proved by the old manuscripts written on 'palm' leaves (7). The knowledge is then passed down through generations, mingling with the habits of the community to create a local wisdom and its use is closely related to people's previous beliefs. According to Katno (4), nowadays the world community tends to back to nature by utilizing plants in overcoming various health problems.
The local community in Southwest Sumba is one of the societies of Eeastern Indonesia that is still closely linked to the customs and ancestral beliefs. The implementation of the ancestral belief encompasses almost every aspect of everyday life, and one of them is the utilization of herbs as a cure ingredient. The knowledge of Southwest Sumba people in utilizing or processing the medicinal plants related to the customs or beliefs of each group community. There are some similarities or differences in its utilization. This distinction creates its own uniqueness possessed by society and it may not be found in other people cultures.

The objectives of this study were: 1 . to know the type of medicinal plants used by the local community of Southwest Sumba; 2. to find the benefits of medicinal plants obtained by local community; 3 . to observe how the community treats the medicinal plants; 4 . to identify the types of diseases that can be cured by the medicinal plants in local communities.

\section{METHOD}

\section{Approach and Research Method}

The method used in this research is descriptive explorative (10).

Place and Time

Southwest Sumba District, in the year of 2015.

Research Implementation and Research Flow

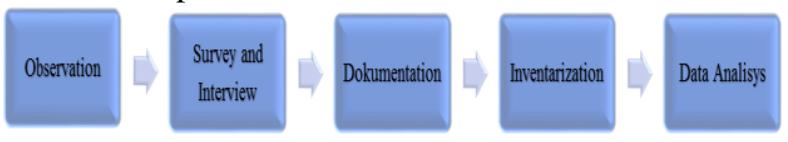

Research implementation and research flow are described as follows:

a). Research sites observation. At this observation, it was conducted at the research location and we observed people who know medicinal plants, elders or traditional chairman, and traditional physicians.

b). Survey and respondents interview. Semi-structured interview method was used during the interview. It was conducted to obtain the required data from all respondents.

c). Plants documentation. After obtaining the data from the interview, then they were documented. There were two forms of documentation, they were photo and video to provide evidence of the existence plants. 
d). Plants inventory. This activity was done after obtaining the data from the plants documentation to know the taxonomy of the herbs.

e). Qualitative descriptive data analysis by analyzing the ethnobotany plants by using content analysis (Satori $\&$ Komariah, 2009). The complete results of data acquisition then will be analyzed and drawn the conclusion as well.

\section{RESULT}

\section{Flora in Southwest Sumba}

\section{General Description of Flora in Southwest Sumba}

The community of Southwest Sumba regency utilizes forest products from timber and shrubs as medicinal plants. There are many types of medicinal plants in Sumba, such as Imperatacylindrica, Areca catechu, Dagalarav (Gloriosasuperba), and Cintakua (Phyllaantusurinaria).
There are 16 species of medicinal plants existed in Southwest Sumba. These medicinal plants are in the form of simplicia and herb. The plants which are in the form of herbs are in Kahale Village, Kodi Balaghar municipality (these herbs consist of kencur, kebalibokolo, cendana, hayuwateyo, aku, ghayomaniris skin, rombo wood, ndaro, kapakehemba) which is added with coconut oil. They can cure poison by the snake bites, broken bones, pregnant women, and prevent the witches attack.

The example of non-simplicia form of medicinal plants is biduri (Calotropisgigantea). Biduri is used as a febrifuge medicine and to overcome the witchcraft. While tabuta is one of the plants used as a snake medicine. In addition, the stem of this plant is one of the many pharmaceutical ingredients grown in the district of Kodi Balaghar and Kodi Bangedo. Parts of plant that commonly used for medicine are leaves, bark, root, and fruit. Leaves are a part of photosynthesis that stores many secondary metabolite compounds such as flavonoids,

Table 1: Plant Type, Plant Section, Treatment Method, Benefits of Medicinal Plants in Southwest Sumba

\begin{tabular}{|c|c|c|c|c|c|}
\hline No & $\begin{array}{c}\text { Type of Plant (local } \\
\text { name) }\end{array}$ & $\begin{array}{c}\text { Parts of Plants that are } \\
\text { used }\end{array}$ & $\begin{array}{l}\text { How to } \\
\text { process }\end{array}$ & Benefit & $\begin{array}{l}\text { Sources of } \\
\text { acquisition }\end{array}$ \\
\hline 1. & $\begin{array}{l}\text { Cendana hutan } \\
\text { (Santalumalnum) }\end{array}$ & leaves & boiled & stomach medicine & in the forest \\
\hline 2. & Kuncup hutan & leaves & $\begin{array}{l}\text { pounded } \\
\text { Boiled with }\end{array}$ & Hot fever & in the garden \\
\hline 3. & $\begin{array}{l}\text { Meniran } \\
\text { (Phyllantusurinaria) }\end{array}$ & leaves & $\begin{array}{l}\text { 'kumis } \\
\text { kucing', } \\
\text { avocado } \\
\text { leaves }\end{array}$ & Bloody urine & in the garden \\
\hline 4. & Kapuk(Ceibapetandra) & leaves & boiled & diarrhea & in the garden \\
\hline 5. & Linyo & leaves & boiled & asthma & in the garden \\
\hline 6. & Ekor kerbau & leaves & boiled & witchcraft & in the garden \\
\hline 7. & $\begin{array}{l}\text { Cinakua } \\
\text { (Phyllantusurinaria) }\end{array}$ & leaves & boiled & $\begin{array}{l}\text { stomach medicine }+ \\
\text { 'kumis kucing 'leaves }\end{array}$ & in the garden \\
\hline 8. & $\begin{array}{l}\text { Kumis kucing woods } \\
\text { (Orthosiphonsp) }\end{array}$ & leaves & $\begin{array}{l}\text { Boiled with } \\
\text { cinatkua } \\
\text { leaves }\end{array}$ & & in the garden \\
\hline 9. & Dagalara (Gloria superba) & leaves & boiled & sore eyes & in the garden \\
\hline 10. & Jambu biji (Guava sp.) & leaves & boiled & diabetes & in the garden \\
\hline 11. & $\begin{array}{l}\text { Alpukat (Persea } \\
\text { americana) }\end{array}$ & $\begin{array}{l}\text { avocado leaves mixed } \\
\text { with meniran leaves and } \\
\text { kumis kucing then drink it }\end{array}$ & boiled & Bloody urine & in the garden \\
\hline 12 & $\begin{array}{l}\text { Gading coconut } \\
\text { (Famili:Arecaceae) }\end{array}$ & coconut water & drink & neutralizes toxins & in the garden \\
\hline 13. & Kunyit (Curcumin $s p$ ) & rhizome & boiled & $\begin{array}{l}\text { Increasing stamina and } \\
\text { endurance }\end{array}$ & in the garden \\
\hline 14. & Ilalang (Ciperus rotundus) & leaves, its sap & boiled & $\begin{array}{l}\text { as a cough medicine, } \\
\text { thrush, acne, whiteness, } \\
\text { toothache (leaves), } \\
\text { dengue fever, bad breath, } \\
\text { menstruation is not } \\
\text { teratus, asthma, sore } \\
\text { throat (leaf and oil), } \\
\text { swollen gums (sap), clean } \\
\text { eyes and smell body. }\end{array}$ & in the garden \\
\hline 15. & $\begin{array}{l}\text { Alang-alang } \\
\quad \text { (Imperata cylindrical) }\end{array}$ & stems, leaves & boiled & fertility drugs & in the garden \\
\hline 16. & Sirih (Piper bettle) & leaves & boiled & $\begin{array}{l}\text { Antiseptic } \\
\text { deworming, scabies, }\end{array}$ & in the garden \\
\hline 17. & Pinang (Areca catechu L) & seed & boiled & $\begin{array}{l}\text { dysentery, kidney stones, } \\
\text { cancer sores and } \\
\text { nosebleeds }\end{array}$ & In the forest \\
\hline
\end{tabular}


terpenoids, and alkaloids that can cure various diseases. The uses of these medicinal plants are by boiling, soaking, pounding, or heating.

\section{Unique Flora, Typical, Framed, Protected and Useful Plants in Southwest Sumba District}

a. Cendana (Santalum album)

Cendana is one of NTT province's identity floras which is excellent because of its distinctive aroma and fragrance and its price is very expensive. Since the 15 th century, Europeans have been hunting for Cendana to NTT, especially to Sumba. The scarcity of Cendana trees started in the $80 \mathrm{~s}$ to $90 \mathrm{~s}$, it was caused by massive logging and exploitation of the forest that were not balanced by good cultivation. Besides, Cendana belongs to hemiparasite flora which requires the host tree for its growth. Therefore, Cendana is difficult to cultivate.

This is what makes Cendana is in the vulnerable category based on IUCN RedList. Cendana is also protected by government based on Law, No. 5 of 1990 on the Conservation of Biological Diversity and Ecosystem and Governmental Regulation, No.7 of 1999 about the Preservation of Plant and Animal Species.

\section{b. Alang-alang (Imperatacylindrica).}

The typical flora that used by the Sumbanese people is alang-alang (CylindricaImperata). The leaves of this plant are used as a roof for traditional houses in Sumba that can last up to a dozen years. In addition, alang-alang is also efficacious to stop bleeding, urine, reduce fever, asthma, nosebleeds, cancer, and tumors. The parts used as medicine are rhizomes and leaves.

\section{c. Sirih (Pipper sp.)}

Sirih leaf and Sirih fruit are used as part of the habit of Sumbanese community. Sirih leaf also has been known to have antibacterial activity and efficacy to cure some diseases such as leucorrhoea and nosebleeds.

\section{d. Pinang (Areca catechu)}

Pinang seeds contain of arecoline compounds that efficacious to cure deworming, scabies, dysentery, kidney stones, cancer sores and nosebleeds.

\section{Medicinal plants utilized by the Society}

Based on the interviews and observation in the research area, some medicinal plants were found and utilized by villagers. There are 17 species that most widely used. See table 1.

These traditional medicinal plants have an important role for the community. Villagers utilize the medicinal plants based on their knowledge that derived from inherited heritage. Medicinal plants are used as the alternative medicine and as first aid treatment can be found in the forest, yard, and garden around them.

Most of the herbaceous medicinal plants of the Southwest Sumba are shrubs and tree (such as: sandalwood, guava, avocado, ivory, kapok). People use medicinal plants in a various ways, but they mostly made them by boiling the leaves before drinking them.

5. The Ethnic Society's View on Medicinal Plants of Southwest Sumba

The limited health center facilities, such as 'Puskesmas', make the people prefer to use traditional medicine to cure their health problems, especially for the inland people who have problems to access the health center. Traditional medicine is usually used as first aid. The ingredients of traditional medicine are easy to find and easy to make, also it is cheaper than modern pharmacy drugs. It becomes their habits that derived from inherited heritage of their anchestor.

In a traditional society, if a person has knowledge, especially the knowledge of local wisdom, then the society will give him/her higher social recognition. This factor also becomes one of the reasons why the traditional medicines being kept confidential and

\begin{tabular}{|c|c|c|c|c|c|c|c|}
\hline $\begin{array}{l}\text { Cendana } \\
\text { hutan } \\
\text { (Santalum } \\
\text { album) }\end{array}$ & $\begin{array}{l}\text { Kuncup } \\
\text { hutan }\end{array}$ & Meniran & $\begin{array}{l}\text { Kapuk } \\
\text { (Ceibapetan } \\
\text { dra) }\end{array}$ & Linyo & Ekorkerbau & $\begin{array}{l}\text { Cintakua } \\
\text { (Phyllantusu } \\
\text { rinaria) }\end{array}$ & $\begin{array}{l}\text { Kumis } \\
\text { kucing } \\
\text { hutan } \\
\text { (Orthosipho } \\
\text { nsp) }\end{array}$ \\
\hline & का & 6 & $N$ & $H=$ & & & \\
\hline $\begin{array}{l}\text { Dagalara } \\
\text { (Gloria } \\
\text { superba) }\end{array}$ & $\begin{array}{l}\text { Jambu biji } \\
\text { (Guava } \\
\text { sp.) }\end{array}$ & $\begin{array}{l}\text { Alpukat } \\
\text { (Persea } \\
\text { americana) }\end{array}$ & $\begin{array}{l}\text { Kelapa } \\
\text { gading } \\
\text { (Famili:Are } \\
\text { caceae) }\end{array}$ & $\begin{array}{l}\text { Kunyit } \\
\text { (Curcumin } \\
\text { sp) }\end{array}$ & $\begin{array}{l}\text { Rumputteki } \\
\text { (Ciperus } \\
\text { rotundus) }\end{array}$ & $\begin{array}{c}\text { Alang-alang } \\
\text { (Imperata } \\
\text { cylindrical) }\end{array}$ & $\begin{array}{l}\text { Sirih } \\
\text { (Piper } \\
\text { bettle) }\end{array}$ \\
\hline
\end{tabular}

Figure 1: Plant Type, Plant Section, Treatment Method, Benefits of Medicinal Plants in Southwest Sumba 
cannot be delivered freely. (Lantik, 1998 in Sabri, 2011).

\section{CONCLUSION}

Based on the results of the research, it can be concluded as follows: 1) the communities in some areas of Southwest Sumba have a unique and different system of medicinal plants utilization that are different from other regions; 2) the people of Southwest Sumba are still familiar with the various types of medicinal plants and their benefits, and how to treat the plants as well; 3) the communities are able to integrate a culture of crop used as herbal medicine as an effort of conservation against local biodiversity. It can be concluded that the community still have strong efforts to cultivate medicinal plants.

\section{REFERENCES}

[1]. Anderson En, Pearsal DM, HunnEs, Turner JN. Ethnobiology. New Jersey (US): John Wiley \& Sons Inc. http://doi.org/b64rhw. 2011

[2]. Hariana, A. Tumbuhan Obat dan Khasiatnya. Jakarta:PenebarSwadaya, 2006
[3]. Hoffman, B. \& Gallaher, T. Importance Imdices in Ethnobotany. Ethnobotany Research Application,5,201-218. 2007

[4]. Katno. Tingkat Manfaat Keamanan Tanaman Obat dan Obat Tradisional. (B2P2TO-OT) BalaiPenelitiandanPengembanganKesehatanDepar temenKesehatan RI. 2008

[5]. Minnis. Ethnobotany. Oklahoma (US): Univ. Oklahoma Pr. 2000

[6]. Pei SJ. Ethnonotany and Sustainavle Use of Biodiversity. Plant and Diversity Resources. 35(4):401-406. 2013

[7]. Satori, Djamaan\&Komariah, MetodologiPenelitianKualitatif, Bandung: Alfabeta. 2009

[8]. Suryadarma. Ethnobotani. [Diktat Kuliah]. UniversitasNegeriYogjakarta. Yogjakarta. 2008

[9]. Trianto. Mengembangkan Model PembelajareanTematik, Jakarta: PT Prestasi. 2010 